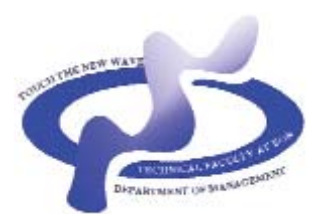

www.sjm06.com

\title{
MANAGING CUSTOMER RELATIONSHIPS IN PRIVATE HEALTH CARE FACILITIES - A STUDY WITH REFERENCE TO GREATER NOIDA CITY OF UTTAR PRADESH
}

\author{
Saroj Kumar Dash ${ }^{a^{*}}$ and Arun Kumar Panda ${ }^{b}$ \\ a Department of Management Studies, Skyline Institute of Engineering and Technology, \\ Greater Noida, Uttar Pradesh, India-201308

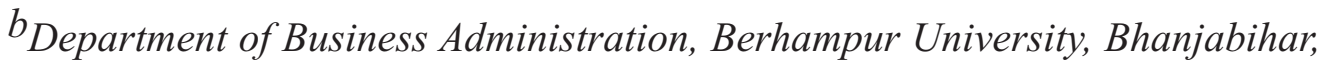 \\ Orissa, India
}

(Received 8 June 2010; accepted 2 October 2010)

\begin{abstract}
Customer relationship management (CRM) which has overriding significance for any business is no less significant for hospital services. Hospitals are most important elements in any health care delivery system. A hospital plays a major role in maintaining and restoring the health of the people. Care of the sick and injured, preventive health care, health research, and training of medical and paramedical staff are general broad functions of a hospital. It involves to the outpatient and inpatient hospital services and on many occasions emergency medical services. An important resource in a hospital is a human resource. This should be particularly emphasized. This should be particularly emphasized in the content of a hospital since relationship of medical staff plays important role in treating patients - the hospital customers. In health care, CRM practices are essentially patient focused strategies that involve effective management of hospital interface and interaction with patients. Effective CRM practices in a hospital may mean providing services related information to a patient very quickly. Responding to the patent appointment and an admission requests promptly, dealing with patient queries and complaints expeditiously, exercising all kinds of flexibilities in serving patients to the patients. This research paper made an attempt to analyze the factors influencing the customers to select the hospital and to suggest better ways and means to retain the customers. For the study, the researcher has collected data from 200 respondents of 10 private hospitals located in Greater Noida city. For this purpose stratified random sampling method was used to select the samples. The present study highlights the extent of utilization of the hospital services by the selected sample respondents. It also shed light on the common problems faced by the respondents. The major features of the service sectors especially on hospital performance is projected in order to utilize the services as per the expectation of the patients (customer).

The collected data were analyzed through percentage, average, range, standard deviation and
\end{abstract}

\footnotetext{
* Corresponding author: sarojdash111@gmail.com
} 
weighted average. Chi-square test was also employed to find the associationship of overall satisfaction with different demographic variables. Likert's scaling technique is used to identify the customer preference and satisfaction on hospital services. Henry Garrets ranking method is also used to judge the ranking especially on the hospital services.

Keywords: Customer Relationship Management, Customer Satisfaction, Garrets ranking method

\section{INTRODUCTION}

The hospital market has today changed from a seller's market to a buyers' market, where the patient is all-important. One needs to understand the fact that patients do not flock to a hospital just because its services are cheap, but because of its good name and good image (Berman and dave, 1994; Engel et al., 2004).

It is essential for a hospital to reach out to its customers (patients), if it wants to survive the competition. This can be achieved only by building a bridge of trust between the hospital and the community, so that the community can cross over to the hospital. The new millennium is in the midst of explosive change witnessing rapidly changing market conditions, volatile equity markets, reconstructed value chains and new global competitors. And customers themselves are changing - natural customer loyalty is a thing of the past. Little wonder then, the concept of Customer Relationship Management (CRM) has taken center stage in the business world for sustainable business advantages. Long-term success requires a great Customer Relationship Management strategy. A technology enabled CRM strategy to meet Customer-focused objectives involves the vast majority of any organization's activity. Today customers are looking for service on channels and regardless of media; this is possible because of new technologies. Customers have experienced new techniques like online, self- help, mail, chat, phone, e-mail, which are making them interact with the company more easily. Some of the major benefits for customer management include the use of latest technologies like universal agent's desktops, CTI, customer data repositories and product knowledge bases. With the latest technologies, other areas like e-commerce, logistics and distribution, marketing services and inbound sales are also coming into the picture and companies have already started implementing the same (Nair, 2009; Stanton 2009; ).

The CRM segment has significantly contributed to the recent IT growth. Less growth in the CRM segment from small and medium sized companies showed that these groups of companies either have fewer resources or they do not have the required skills to generate positive results from CRM investments. In the new economy only a few organizations are providing their customers high quality products and service experience. They are reaching, interacting and transacting with customers through multiple channels and providing them ultimate satisfaction. Customers do not have the same value similarly all organizations cannot adopt a full-fledged CRM model. In some cases, the cost of developing a CRM infrastructure may prove to be greater than the returns involved. The world economy is becoming an increasingly volatile system. Any enterprise that can make volatility its "Friend" by adapting quickly to changes in the external environment will be rewarded 
with success and growth (Basu, 2003; Government of India, 2004)).

Success at harnessing the full value, of the customer is increasingly dependent on the effectiveness of your relationships not only with customers themselves, but also with suppliers and partners. Adaptive companies are those that are not only integrated internally, but which are also connected to the outside world. The competition for the most profitable customer relationship is fierce. To win the battle, companies have to provide customers with a consistently highquality experience and be able to manage this over time, and across a multitude of touch-points. "You've got to know who your customers are - their habits, their preference, their experiences with you, and their ultimate value to you - if you want to thrive in today's relationship economy" (Gupta, 2000; Zivkovic et al., 2010).

At the same time, the congestion for customers, along with abundant customer's choices, has pushed customer expectations to new heights. Who has the patience for a provider that doesn't deliver on time with quality - and with a burning desire to satisfy their needs? Who wants to be bombarded with the same promotion after saying "yes" the first time? Adding to the challenge, a company is providing more across points than ever before to reach and interacts with customers (Revathy, 2003; Saran, 2004; Hasan, 2003). Not only the companies have more channels to manage and integrate, channels like the Internet have made it easier for customers to shop for the best service and deals, creating even more competition for the same customer base. Customers are demanding that you are accessible and easy to do business with.

Well, does CRM have any role in improving business performance? While the paths to winning the hearts and wallets of your customers are as varied as your customers themselves, the first step is to define the stages of the customer experience from the customer's point of view. Then you must determine how to invest in each stage to generate the greatest customer and business impact. Global companies are beginning to implement CRM strategies, tools and infrastructure to acquire new and leverage existing relationships (Kothari, 1990; Kotler 2000; Umukoro et al., 2009).

Indeed, a third of the sales, marketing and customer services executives' recently surveyed view of almost CRM are demonstrated by the finding that $65 \%$ of the companies surveyed expect an increase in the IT budget for CRM during 2008. Overall CRM efforts are transitioning from point or departmental solutions to more enterprisewide initiatives. The true value of CRM in building profitable relationships is dependent on understanding that is an enterprise-level strategy that presents a unified organization and experience to the customer.

\section{STATEMENT OF THE PROBLEM}

The new millennium is in the midst of explosive change witnessing rapidly changing market conditions, volatile equity markets, reconstructed value chains and new global competitors. And Customers themselves are changing - natural customer loyalty is a thing of the past. Little wonder then, the concept of customer relationship management (CRM) has taken center stage in the business world for sustainable business advantages. Long-term success requires a great Customer Relationship Management strategy. A technology-enabled CRM strategy to meet Customer-focused 
objectives involves the vast majority of any organization's activity. No doubt about that Customer Relationship Management (CRM) has become a top priority for companies seeking to gain competitive advantage in today's stormy economy. However, confusion reigns about exactly what CRM is, how to best implement it, or even what role it should play in enhancing customer interaction. Against this background, it will be worth, undertaking a study to evaluate the consumer retention of selected hospital (Oillai and Bagavathi, 2009).

\section{OBJECTIVES OF THE STUDY}

The following are the specific objectives of the study:

1. To examine the present system of customer care in Hospital,

2. To analyze the factors influencing the customers to select the hospital,

3. To study the competitive strategies of hospitals in Greater Noida city and

4. To suggest better ways and means to retain the customers.

\section{RESEARCH METHODOLOGY}

The validity of any research is based on the systematic method of data collection and analysis. Both primary and secondary data were used for the present study. The primary data has been collected from 200 sample respondents in Greater Noida city. For this purpose stratified random sampling method was used to select the samples. The researcher has approached the managers of various hospitals in Greater Noida city to collect the list of customers in the hospitals. Due to time, money and inconvenience, the researcher has selected only top ten hospitals in the Greater Noida city. The questionnaires were collected from 200 respondents from 10 reputed hospitals. The ten hospitals selected for this study were Naveen Hospital, Kailash Hospital, Aastha Hospital, Sharda Hospital, Prakash Hospital, NIMT Hospital, Prayag Hospital, Shri Krishna Hospital, Surya Hospital and Sahdev Hospital. The present study highlights the extent of utilization of the hospital services by the selected sample respondents. It also shed light on the common problems faced by the respondents. The major features of the service sectors especially on hospital performance is projected in order to utilize the services as per the expectation of the patients (customer).

For this study data have been collected from both primary and secondary source. An exclusive field study and interview have been conducted. It included rural semi-urban areas, business, employed and self-employed from both genders are identified and the sampling unit is finalized. Interview schedule was the main tool used to collect the pertinent data from the selected sample respondents. Secondary data have also been collected for the study from books, leading journals, newspapers, magazines and textbooks related to study and from the internet sources. The collected data were analyzed through percentage, average, range, standard deviation and weighted average. In connection with this two way Tables were prepared and chi-square test were also employed to find the associationship. Likert's scaling technique is used to identify the customer preference and satisfaction on hospital services. Henry Garrets ranking method is also used to judge the ranking especially on the hospital services. The study is confined to a period of 6 months since May 2010 to August 2010. 


\section{ANALYSIS AND INTERPRETATION OF DATA}

Customer relationship is the crucial element in the marketing function, which decides the goodwill of any concern. An attempt is made to analyze the various factors influencing the customer relation level of the selected sample respondents. The variables are classified into two important strata viz. Dependent variables and Independent variables. The level of relationship of customer is taken as the dependent variables. The independent variables used in the study are age, gender, category, marital status, monthly income, occupation and educational qualification.

\section{AGE AND LEVEL OF SATISFACTION ON CRM}

Age is an important factor in customer relationship management. Hence, the respondents have been grouped under three categories viz. Below 25 years, 26-30 years and above 30 years. The sample consisted of 88 respondents $(44 \%)$ below 25 years, 74 respondents belong to (37\%) 26 to 30 years and $38(19 \%)$ respondents belong to above 30 years. The distribution of respondents according to age is observed from the following Table. It could be observed from Table 1 that level of satisfaction on customer relationship management among the respondents of below 25 years category ranged between 35 and 51 with an average of 43.83. Level of satisfaction on customer relationship management between 26-30 years category of respondents ranged between 36 and 53 with an average of 45.84 . On the other hand, the respondent's level of satisfaction on customer relationship management among the above 30 years category ranged between 45 and 56 with an average of 50.00. Thus, it may be concluded from the analysis that respondents of the age above 30 years are having maximum level of satisfaction. Using chi-square test the age and level of satisfaction on CRM has been tested. For this purpose, the age and level of satisfaction on CRM are given in the following Table.

Null hypothesis: The association between the age of the respondents and their

Table 1. Age and level of satisfaction

\begin{tabular}{|c|c|c|c|c|c|c|c|c|c|}
\hline \multirow{2}{*}{ SI. No. } & \multirow{2}{*}{ Age Group } & \multicolumn{3}{|c|}{ Level of satisfaction } & \multirow{2}{*}{ Total } & \multirow{2}{*}{ Average } & \multicolumn{2}{|c|}{ Range } & \multirow{2}{*}{ S.D } \\
\hline & & Low & Medium & High & & & Min & Max & \\
\hline 1. & Below 25 years & $\begin{array}{c}21 \\
(14.96)\end{array}$ & $\begin{array}{c}35 \\
(26.40)\end{array}$ & $\begin{array}{c}32 \\
(46.64)\end{array}$ & 88 & 43.83 & 35 & 51 & 5.08 \\
\hline 2. & $26-30$ years & $\begin{array}{c}13 \\
(12.58)\end{array}$ & $\begin{array}{c}16 \\
(22.20)\end{array}$ & $\begin{array}{c}45 \\
(39.22)\end{array}$ & 74 & 45.84 & 36 & 53 & 5.43 \\
\hline 3. & Above 30 years & $\begin{array}{c}0 \\
(6.46)\end{array}$ & $\begin{array}{c}9 \\
(11.40)\end{array}$ & $\begin{array}{c}29 \\
(20.14)\end{array}$ & 38 & 50.00 & 45 & 56 & 3.98 \\
\hline & Total & 34 & 60 & 106 & 200 & & & & \\
\hline
\end{tabular}

Source: Survey Data (Figures given in the brackets represent the Expected Frequency) 
level of satisfaction on CRM is not statistically significant.

The percentage of high level of satisfaction is the highest (42.5) among the 26-30 years age group and the lowest (27.4) among the above 30 years age group. The percentage of medium level of satisfaction is the highest (58.3) among the aged below 25 years respondents and the lowest (15) among the above 30 years aged respondents. On the other hand, the percentage of low level of satisfaction is the highest (61.8) among the respondents aged below 25 years and the lowest (38.2) among the 26-30 years aged respondents. As the calculated chi-square value (23.295) is greater than the Table value (9.488) at 5\% level of significance for 4 degrees of freedom, the null hypothesis is rejected and it could be concluded that the association between the age of the respondents and their level of satisfaction on CRM is statistically significant.

\section{GENDER AND LEVEL OF SATISFACTION ON CRM}

Today there is no discrimination to study the level of satisfaction on customer's relationship in any kind of product and services among the male and female group. Today women are equally competing with men in all the fields, including business, military organization and space research centers. In this study, most of the business activities are supported by women (especially financial support). For the purpose of the study, gender classification is observed. The sample consists of 134 (67\%) male respondents and 66 (33\%) female respondents. The distribution of respondents according to sex and level of satisfaction on customer's relationship is shown in the Table 2. The maximum level of satisfaction on customer's relationship among the female respondents ranged between 37 and 54 with an average of 46.38. Whereas, male respondents level of satisfaction on customer's relationship ranged between 35 and 56 with an average of 45.43. Thus the Table reveals that the maximum level of satisfaction on customer's relationship is among the female respondents. Using chisquare test the gender and level of satisfaction on CRM has been tested. For this purpose, the gender and level of satisfaction on CRM are given in the following Table.

Null hypothesis: The association between the gender of the respondents and

Table 2. Gender and level of satisfaction on CRM

\begin{tabular}{|c|c|c|c|c|c|c|c|c|c|}
\hline \multirow{2}{*}{ Sl. No. } & \multirow{2}{*}{ Gender } & \multicolumn{3}{|c|}{ Level of satisfaction } & \multirow{2}{*}{ Total } & \multirow{2}{*}{ Average } & \multicolumn{2}{|c|}{ Range } & \multirow{2}{*}{ S.D } \\
\hline & & Low & Medium & High & & & Min & Max & \\
\hline 1. & Male & $\begin{array}{l}26 \\
(22.78)\end{array}$ & $\begin{array}{l}38 \\
(40.20)\end{array}$ & $\begin{array}{l}70 \\
(71.02)\end{array}$ & 134 & 45.43 & 35 & 56 & 5.55 \\
\hline 2. & Female & $\begin{array}{l}8 \\
(11.22)\end{array}$ & $\begin{array}{l}22 \\
(19.8)\end{array}$ & $\begin{array}{l}36 \\
(34.98)\end{array}$ & 66 & 46.38 & 37 & 54 & 5.35 \\
\hline & Total & 34 & 60 & 106 & 200 & & & & \\
\hline
\end{tabular}

Source: Survey Data (Figures given in the brackets represent the Expected Frequency) 
their level of satisfaction on CRM is not statistically significant.

The percentage of high level of satisfaction on customer's relationship is the highest (66.0) among the male respondents and the lowest (34.0) among the female respondents. The percentage of medium level of satisfaction on customer's relationship is the highest (63.3) among the male respondents and the lowest (36.7) among the female respondents. On the other hand, the percentage of level of satisfaction on customer's relationship is the highest (76.5) among the male respondents and the lowest (23.5) among the female respondents. As the calculated chi-square value (1.788) is less than the Table value (5.991) at 5\% level of significance for 2 degrees of freedom, the null hypothesis is accepted and it could be concluded that the association between the gender of the respondents and their level of satisfaction on CRM is not statistically significant.

\section{CATEGORY AND LEVEL OF SATISFACTION}

The level of satisfaction may be varying according to the types of customers. For the purpose of the study, category sample consists of $40(20 \%)$ in-patient respondents, $78(39 \%)$ out-patient respondents and 82 (42\%) attenders respondents. The distribution of respondents according to category and level of satisfaction on customer's relationship is shown in the following Table 3. The maximum level of satisfaction on customer's relationship among the in-patient respondents ranged between 39 and 54 with an average of 47.15. On the other hand the respondents' level of satisfaction on customer's relationship among the Out-patient respondents ranged between 41 and 52 with an average of 47.05, whereas attenders level of satisfaction on customer's relationship ranged between 35 and 56 with an average of 43.82. Using chisquare test the category of customers and level of satisfaction on CRM has been tested. For this purpose, the category of customers and level of satisfaction on CRM are given in the following Table.

Null hypothesis: The association between the category of the respondents and their level of satisfaction on CRM is not statistically significant.

The percentage of high level of satisfaction on customer's relationship is the highest (48.1) among the Out-patient respondents and the lowest (22.6) among the In-patient respondents. The percentage of medium level of satisfaction on customer's relationship is the highest (45.0) among the Out-patient respondents and the lowest (20.0) among the In-patient respondents. On the other hand, the percentage of low level of satisfaction on customer's relationship is the highest (88.2) among the attenders' respondents and the lowest (0.0) among the Out-patient respondents. As the calculated chi-square value (50.560) is greater than the Table value (9.488) at 5\% level of significance for 4 degrees of freedom, the null hypothesis is rejected and it could be concluded that the association between the category of the respondents and their level of satisfaction on CRM is statistically significant.

\section{MARITAL STATUS AND LEVEL OF SATISFACTION}

Marital status is an important factor to find the level of satisfaction. For the purpose 
Table 3. Category of customers and level of satisfaction on CRM

\begin{tabular}{|c|c|c|c|c|c|c|c|c|c|}
\hline \multirow{2}{*}{$\begin{array}{l}\text { SI. } \\
\text { No. }\end{array}$} & \multirow{2}{*}{ Category } & \multicolumn{3}{|c|}{ Level of satisfaction } & \multirow{2}{*}{ Total } & \multirow{2}{*}{ Average } & \multicolumn{2}{|c|}{ Range } & \multirow{2}{*}{ S.D } \\
\hline & & Low & Medium & High & & & Min & Max & \\
\hline 1. & In-patient & $\begin{array}{l}4 \\
(6.8)\end{array}$ & $\begin{array}{l}12 \\
(12.0)\end{array}$ & $\begin{array}{l}24 \\
(21.20)\end{array}$ & 40 & 47.15 & 39 & 54 & 4.22 \\
\hline 2. & Out-patient & $\begin{array}{l}0 \\
(13.26)\end{array}$ & $\begin{array}{l}27 \\
(23.40)\end{array}$ & $\begin{array}{l}51 \\
(41.34)\end{array}$ & 78 & 47.05 & 41 & 52 & 3.54 \\
\hline 3. & Attenders & $\begin{array}{l}30 \\
(13.94)\end{array}$ & $\begin{array}{l}21 \\
(24.60)\end{array}$ & $\begin{array}{l}31 \\
(43.46)\end{array}$ & 82 & 43.82 & 35 & 56 & 6.86 \\
\hline & Total & 34 & 60 & 106 & 200 & & & & \\
\hline
\end{tabular}

Source: Survey Data (Figures given in the brackets represent the Expected Frequency)

of this study marital status has been studied under three heads viz., Single, Married and widow. The study sample consists of 93 (46.5\%) single category respondents, 104 $(52 \%)$ married category respondents and 3 $(1.5 \%)$ widow category respondents. The distribution of respondents according to category and level of satisfaction on customer's relationship is shown in the Table 4. The maximum level of satisfaction on customer's relationship among the married category respondents ranged between 36 and 56 with an average of 47.12. On the other hand the respondents' level of satisfaction on customer's relationship among the single category respondents ranged between 35 and 51 with an average of 44.20 , whereas widow category level of satisfaction on customer's relationship ranged at 46 with an average of 46. The study reveals that the maximum level of satisfaction on customer's relationship is among the married category respondents in the study area. Using chisquare test the marital status and level of satisfaction on CRM has been tested. For this purpose, the marital status and level of satisfaction on CRM are given in the following Table.

Null hypothesis: The association between the marital status of the respondents and their level of satisfaction on CRM is not statistically significant.

It is found that the percentage of high level of satisfaction on customer relationship is highest (62.3) among married respondents and the lowest (2.8) among widow category respondents. The normal level of satisfaction on customer relationship is highest (61.8) among the single category respondents and lowest is widow category which has no respondent. On the other hand, the percentage of low level of customer relationship is the highest (61.8) among single category respondents and lowest is widow which has no respondent. As the calculated chi-square value (13.752) is greater than the Table value (9.488) at 5\% level of significance for 4 degrees of freedom, the null hypothesis is rejected and it could be concluded that the association 
Table 4. Marital status and level of satisfaction on CRM

\begin{tabular}{|c|c|c|c|c|c|c|c|c|c|}
\hline \multirow{2}{*}{ Sl. No. } & \multirow{2}{*}{$\begin{array}{l}\text { Marital } \\
\text { Status }\end{array}$} & \multicolumn{3}{|c|}{ Level of satisfaction } & \multirow{2}{*}{ Total } & \multirow{2}{*}{ Average } & \multicolumn{2}{|c|}{ Range } & \multirow{2}{*}{ S.D } \\
\hline & & Low & Medium & High & & & Min & Max & \\
\hline 1. & Single & $\begin{array}{l}21 \\
(15.81)\end{array}$ & $\begin{array}{l}35 \\
(27.9)\end{array}$ & $\begin{array}{l}37 \\
(49.29)\end{array}$ & 93 & 44.20 & 35 & 51 & 5.12 \\
\hline 2. & Married & $\begin{array}{l}13 \\
(17.68)\end{array}$ & $\begin{array}{l}25 \\
(31.20)\end{array}$ & $\begin{array}{l}66 \\
(55.12)\end{array}$ & 104 & 47.12 & 36 & 56 & 5.55 \\
\hline 3. & Widow & $\begin{array}{l}0 \\
(0.51)\end{array}$ & $\begin{array}{l}0 \\
(0.9)\end{array}$ & $\begin{array}{l}3 \\
(1.59)\end{array}$ & 3 & 46.00 & 46 & 46 & 0.00 \\
\hline & Total & 34 & 60 & 106 & 200 & & & & \\
\hline
\end{tabular}

Source: Survey Data (Figures given in the brackets represent the Expected Frequency)

between the marital status of the respondents and their level of satisfaction on CRM is statistically significant.

\section{MONTHLY INCOME AND LEVEL OF SATISFACTION}

Patients make the choice of the hospital or doctor based on their income for normal treatments. Hence, the researcher has given utmost importance to the monthly earning of respondents. For the purpose of the study income has been studied under three heads viz. namely below Rs.15000, Rs.15001 to Rs.18000 and Rs.18001 and above. The sample consists of $66(33 \%)$ respondents from below Rs.15000 category, 64 (32\%) respondents from Rs.15001 to Rs. 18000 category and 70 (35\%) from Rs.18001 and above category. The distribution of respondents according to the income and level of satisfaction on customer's relationship is shown in the following Table. It is observed from the Table 5 that maximum level of satisfaction on Customer Relationship is among the Rs.15001 to Rs.18000 income group which has ranged between 41 and 54 with an average of 48.70 . The level of satisfaction of Customer Relationship among the Rs.18001 and above income group ranged between 36 and 56 with an average of 45.26. On the other hand the below Rs.15000 income group with a range of 35 and 51 has an average of 43.39. Thus it may be concluded that the level of satisfaction on Customer Relationship is maximum among Rs.15001 to Rs. 18000 income group of respondents. Using chisquare test the monthly income and level of satisfaction on CRM has been tested. For this purpose, the monthly income and level of satisfaction on CRM are given in the following Table.

Null hypothesis: The association between the monthly income of the respondents and their level of satisfaction on CRM is not statistically significant.

It is found that the percentage of high level of satisfaction on Customer Relationship is highest (44.3) among Rs.15001 to Rs.18000 income group of respondents and the lowest (24.5) among the below Rs.15000 income group of people. The medium level of satisfaction of Customer Relationship is the highest (40) 
Table 5. Monthly income and level of satisfaction on CRM

\begin{tabular}{|c|c|c|c|c|c|c|c|c|c|}
\hline \multirow{2}{*}{$\begin{array}{l}\text { Sl. } \\
\text { No. }\end{array}$} & \multirow{2}{*}{ Monthly Income } & \multicolumn{3}{|c|}{ Level of satisfaction } & \multirow{2}{*}{ Total } & \multirow{2}{*}{ Average } & \multicolumn{2}{|c|}{ Range } & \multirow{2}{*}{ S.D } \\
\hline & & Low & Medium & High & & & Min & Max & \\
\hline 1. & Below Rs. 15000 & $\begin{array}{l}21 \\
(11.22)\end{array}$ & $\begin{array}{l}19 \\
(19.8)\end{array}$ & $\begin{array}{l}26 \\
(34.98)\end{array}$ & 66 & 43.39 & 35 & 51 & 5.24 \\
\hline 2. & $\begin{array}{l}\text { Rs.15001 to } \\
\text { Rs.18000 }\end{array}$ & $\begin{array}{l}0 \\
(10.88)\end{array}$ & $\begin{array}{l}17 \\
(19.2)\end{array}$ & $\begin{array}{l}47 \\
(33.92)\end{array}$ & 64 & 48.70 & 41 & 54 & 3.93 \\
\hline 3. & Rs.18001 \& above & $\begin{array}{l}13 \\
(11.90)\end{array}$ & $\begin{array}{l}24 \\
(21.0)\end{array}$ & $\begin{array}{l}33 \\
(37.10)\end{array}$ & 70 & 45.26 & 36 & 56 & 5.77 \\
\hline & Total & 34 & 60 & 106 & 200 & & & & \\
\hline
\end{tabular}

Source: Survey Data (Figures given in the brackets represent the Expected Frequency)

among the Rs.18001 and above category and lowest (28.3) among the Rs.15001 to Rs.18000 income group. The low level of satisfaction on Customer Relationship is highest (61.8) among below Rs.15000 income respondents and lowest is Rs.15001 to Rs.18000 category, which has no respondent. As the calculated chi-square value (28.022) is greater than the Table value (9.488) at 5\% level of significance for 4 degrees of freedom, the null hypothesis is rejected and it could be concluded that the association between the monthly income of the respondents and their level of satisfaction on CRM is statistically significant.

\section{OCCUPATION AND LEVEL OF SATISFACTION}

Occupation is an important factor in determining the level of satisfaction on Customer Relationship. For the purpose of this study occupation has been studied under six heads viz. government employees, private company employees, business men, farmers, housewives and others. The sample consists of 8 (4) respondents from Government employee, 24 (12) respondents are working in the private companies, 21 (10.5) respondents are running their own business, 37 (18.5) are farmers, 16 (8) are house wives and 94 (47) respondents belong to others category. The distribution of respondents according to occupation and level of satisfaction in utilizing the services of hospital is shown in the following Table 6. The maximum level of satisfaction on Customer Relationship is among the housewives, which has ranged between 45 to 54 with an average of 51.5. The level of satisfaction of CRM among the farmers ranged between 41 and 54 with an average of 48.30. The level of satisfaction of CRM among the others category respondents has ranged between 35 and 53 with an average of 44.61. The level of satisfaction of CRM among the private employees has ranged between 36 and 51 with an average of 44.50. The level of satisfaction of CRM among the businessmen has ranged between 37 and 56 with an average of 44.43. On the other hand, the level of satisfaction of CRM among the government employees has ranged at 43 with 
an average of 43.00. Thus, it is concluded that the level of satisfaction on customer relationship is maximum among the housewives. Using chi-square test the occupation and level of satisfaction on CRM has been tested. For this purpose, the occupation and level of satisfaction on CRM are given in the following Table.

Null hypothesis: The association between the occupation of the respondents and their level of satisfaction on CRM is not statistically significant.

The percentage of high level of satisfaction in utilizing hospital services is the highest (38.7) among the other groups. The percentage of high level of satisfaction in utilizing hospital services is the highest (15) among others group and the same is the lowest (9) among the Private Company Employees. The percentage of medium level of satisfaction in utilizing hospital services is the highest (8) among the others group and the same is the lowest (0) among the
Government Employee. As the calculated chi-square value (60.094) is greater than the Table value (18.307) at 5\% level of significance for 10 degrees of freedom, the null hypothesis is rejected and it could be concluded that the association between the occupation of the respondents and their level of satisfaction on CRM is statistically significant.

\section{EDUCATIONAL QUALIFICATION AND LEVEL OF SATISFACTION}

Education of the respondents is one of the most important influencing factors of the study. It is acquiring or imparting skills, values and knowledge. Education also means preparing people to develop new ideas and to adjust to the changing environment. For this purpose the respondents have been classified according to their educational level viz. illiterate, higher secondary, under graduation

Table 6. Occupation and level of satisfaction on CRM

\begin{tabular}{|c|c|c|c|c|c|c|c|c|c|}
\hline \multirow{2}{*}{$\begin{array}{l}\text { Sl. } \\
\text { No. }\end{array}$} & \multirow{2}{*}{ Occupation } & \multicolumn{3}{|c|}{ Level of satisfaction } & \multirow{2}{*}{ Total } & \multirow{2}{*}{ Average } & \multicolumn{2}{|c|}{ Range } & \multirow{2}{*}{ S.D } \\
\hline & & Low & Medium & High & & & Min & Max & \\
\hline 1. & $\begin{array}{l}\text { Government } \\
\text { Employees }\end{array}$ & $\begin{array}{l}0 \\
(1.36)\end{array}$ & $\begin{array}{l}8 \\
(2.4)\end{array}$ & $\begin{array}{l}0 \\
(4.24)\end{array}$ & 8 & 43.00 & 43 & 43 & 0.00 \\
\hline 2. & $\begin{array}{l}\text { Private } \\
\text { Company } \\
\text { Employees } \\
\end{array}$ & $\begin{array}{l}9 \\
(4.08)\end{array}$ & $\begin{array}{l}0 \\
(7.2)\end{array}$ & $\begin{array}{l}15 \\
(12.72)\end{array}$ & 24 & 44.50 & 36 & 51 & 6.53 \\
\hline 3. & Businessmen & $\begin{array}{l}8 \\
(3.57)\end{array}$ & $\begin{array}{l}5 \\
(6.3)\end{array}$ & $\begin{array}{l}8 \\
(11.13)\end{array}$ & 21 & 44.43 & 37 & 56 & 7.27 \\
\hline 4. & Farmers & $\begin{array}{l}0 \\
(6.29) \\
\end{array}$ & $\begin{array}{l}8 \\
(11.1) \\
\end{array}$ & $\begin{array}{l}29 \\
(19.61) \\
\end{array}$ & 37 & 48.30 & 41 & 54 & 3.85 \\
\hline 5. & Housewives & $\begin{array}{l}0 \\
(2.72)\end{array}$ & $\begin{array}{l}3 \\
(4.8)\end{array}$ & $\begin{array}{l}13 \\
(8.48)\end{array}$ & 16 & 51.50 & 45 & 54 & 3.31 \\
\hline 6. & Others & $\begin{array}{l}17 \\
(15.98)\end{array}$ & $\begin{array}{l}36 \\
(28.2) \\
\end{array}$ & $\begin{array}{l}41 \\
(49.82) \\
\end{array}$ & 94 & 44.61 & 35 & 53 & 4.90 \\
\hline & Total & 34 & 60 & 106 & 200 & & & & \\
\hline
\end{tabular}

Source: Survey Data (Figures given in the brackets represent the Expected Frequency) 
and post graduation level. Out of 200 respondents, $7(3.5 \%)$ respondents are Illiterate, $37(18.5 \%)$ respondents are higher secondary $122(61.0 \%)$ respondents are under graduates and $34(17.0 \%)$ respondents are post graduates. The distribution of respondents according to education and level of satisfaction on CRM is shown in the following Table 7. The level of satisfaction on CRM based on educational qualification in utilizing hospital services ranged between 39 and 46 with an average of 42 among Illiterate. The level of satisfaction among people with Higher Secondary qualification ranged between 45 and 54 with an average of 50. The range of Under Graduates and Post Graduates level of satisfaction in utilizing hospital services is between 35 and 53 and between 36 and 56 with an average of 45.14 and 44.06 respectively. From the analysis it is inferred that the maximum level of satisfaction is found among Higher Secondary qualified customers. A two way Table is prepared and is shown below. Using chi-square test the educational qualification and level of satisfaction on CRM has been tested. For this purpose, the education and level of satisfaction on CRM are given in the following Table.

Null hypothesis: The association between the educational qualification of the respondents and their level of satisfaction on CRM is not statistically significant.

The percentage of high level of satisfaction in utilizing hospital services is the highest (55.7) among the under graduate category and same is the lowest (2.8) among the Illiterate. The percentage of medium level of satisfaction in utilizing hospital services is the highest (70) under among graduates and the same is the lowest (0) among the illiterate. The percentage of low level of satisfaction in utilizing hospital services is the highest (61.8) among the under graduates and the same is the lowest (0) among the respondents with HSC qualification. As the calculated chi-square value (32.211) is greater than the Table value (12.592) at 5\% level of significance for 6 degrees of freedom, the null hypothesis is rejected and it could be concluded that the association between the educational

Table 7. Educational qualification and level of satisfaction on CRM

\begin{tabular}{|c|c|c|c|c|c|c|c|c|c|}
\hline \multirow{2}{*}{ Sl. No. } & \multirow{2}{*}{$\begin{array}{l}\text { Educational } \\
\text { Qualification }\end{array}$} & \multicolumn{3}{|c|}{ Level of satisfaction } & \multirow{2}{*}{ Total } & \multirow{2}{*}{ Average } & \multicolumn{2}{|c|}{ Range } & \multirow{2}{*}{ S.D } \\
\hline & & Low & Medium & High & & & Min & Max & \\
\hline 1. & Illiterate & $\begin{array}{l}4 \\
(1.19)\end{array}$ & $\begin{array}{l}0 \\
(2.1)\end{array}$ & $\begin{array}{l}3 \\
(3.71)\end{array}$ & 7 & 42.00 & 39 & 46 & 3.74 \\
\hline 2. & HSC & $\begin{array}{l}0 \\
(6.29)\end{array}$ & $\begin{array}{l}5 \\
(11.1)\end{array}$ & $\begin{array}{l}32 \\
(19.61)\end{array}$ & 37 & 50.00 & 45 & 54 & 3.35 \\
\hline 3. & Under Graduation & $\begin{array}{l}21 \\
(20.74)\end{array}$ & $\begin{array}{l}42 \\
(36.6)\end{array}$ & $\begin{array}{l}59 \\
(64.66)\end{array}$ & 122 & 45.14 & 35 & 53 & 5.21 \\
\hline 4. & Post Graduation & $\begin{array}{l}9 \\
(5.78)\end{array}$ & $\begin{array}{l}13 \\
(10.2)\end{array}$ & $\begin{array}{l}12 \\
(18.02)\end{array}$ & 34 & 44.06 & 36 & 56 & 6.32 \\
\hline & Total & 34 & 60 & 106 & 200 & & & & \\
\hline
\end{tabular}

Source: Survey Data (Figures given in the brackets represent the Expected Frequency) 
qualification of the respondents and their level of satisfaction on CRM is statistically significant.

\section{EXISTING FACILITIES IN THE HOSPITALS - HENRY GARRETT RANKING}

An attempt is made to analyze the reasons for selecting the hospital. Various factors such as doctor's treatment, room cleanliness, lab service, pharmacy service, emergency service, canteen service, fees, nursing, reception service, ambulance service, dietician and insurance are selected for the purpose of the study. The respondents are asked to rank their preferences based on the factors that motivated them most. Table 8 shows the details of various factors that influenced the respondents.

Table 8 indicates that the 'Doctors Treatment' 'Cleanliness' and 'Nursing are the main motivating factors that influenced them to select the hospital which is ranked first, second and third with the score of 15082, 13056 and 11559 points respectively. The factors like Emergency Service, Lab
Service, and Ambulance Service are ranked to fourth, fifth and sixth position with the score of 10725, 10078 and 9898 respectively. Pharmacy Service, Reception Service, Insurance and Dietician are ranked in the seventh, eighth, ninth and tenth positions with Garret scores of 9482, 8900, 8239 and 8083 points respectively. The last two positions are occupied by canteen and fees are ranked in the eleventh and twelfth place with a score of 8051 and 7561 points respectively. From the analysis it is concluded that the 'Doctors Treatment' 'Cleanliness' and 'Nursing were the main factors in choosing the hospitals.

\section{PERFORMANCE OF THE HOSPITAL IN RESPECT OF TREATMENT}

Success of any service depends upon competitive factors that differentiate the services with competitive advantages over traditional services. A selected hospital holds some competitive advantage over other traditional hospitals. The Table 9 shows the competitive gains of hospitals.

Table 8. Existing facilities in the hospitals

\begin{tabular}{|l|l|l|l|l|}
\hline SI. No. & Various Facilities & Total Score & Mean Score & Rank \\
\hline 1. & Doctors Treatment & 15082 & 75.4 & I \\
\hline 2. & Room Cleanliness & 13056 & 65.3 & II \\
\hline 3. & Lab Service & 10078 & 50.4 & V \\
\hline 4. & Pharmacy Service & 9482 & 47.4 & VII \\
\hline 5. & Emergency Service & 10725 & 53.6 & IV \\
\hline 6. & Canteen Service & 8051 & 40.3 & XI \\
\hline 7. & Fees & 7561 & 37.8 & XII \\
\hline 8. & Nursing & 11559 & 57.8 & III \\
\hline 9. & Reception Service & 8900 & 44.5 & VIII \\
\hline 10. & Ambulance Service & 9898 & 49.5 & VI \\
\hline 11. & Dietician & 8083 & 40.4 & X \\
\hline 12. & Insurance & 8239 & 41.2 & IX \\
\hline
\end{tabular}


It is noted from the above Table that Pediatrics is ranked first among all the services with 12520 Garret points which distinguishes the hospital from other traditional hospitals. The second rank is given to Cardiology with Garret score of 11216. Gynecology, Neurology and Ortho are secured third, fourth and fifth with score of 55.50, 53.67 and 49.21 respectively. The Gastroenterology, ENT and Physiotherapist were secured sixth, seventh and eighth rank with score of 9368, 9014 and 8552 respectively. The last preference is given for Urology with 40.39 points. From the analysis it is found that Pediatrics is the major competitive advantage gained by the hospital when compared to other traditional hospitals.

\section{SUGGESTIONS}

1. From the analysis it is observed that advertisement does not play a major role. The management should create awareness about their services in local television channels like City Greater Noida and local news papers like Greater Noida Focus and Jagaran City to attract the beneficiaries.

2. Doctor's treatment is the prime factor to select the hospital for their treatment. Hence, it is suggested that the management puts more efforts to sustain the doctor's quality and recruit talented doctors if necessary.

3. Management should concentrate on free camps, mobile services and plying free transport services to the hospital to turn-up the new customers.

4. Management should slowly change its services from traditional to technology based services by acquiring new technology i.e. implementing effective CRM system.

5. Recruitment and training of staff should be standardized.

6. Hospital Management should increase the physician referral centers and

7. Implementing feedback, complaint

Table 9. Performance of the hospital in respect of treatment

\begin{tabular}{|l|l|l|l|l|}
\hline Sl. No. & Types of treatment & $\begin{array}{l}\text { Total } \\
\text { Score }\end{array}$ & $\begin{array}{l}\text { Mean } \\
\text { Score }\end{array}$ & Rank \\
\hline 1. & Cardiology & 11216 & 62.60 & II \\
\hline 2. & Gastroenterology & 9368 & 46.84 & VI \\
\hline 3. & Neurology & 10734 & 53.67 & IV \\
\hline 4. & Gynecology & 11099 & 55.50 & III \\
\hline 5. & Ortho & 9841 & 49.21 & V \\
\hline 6. & Urology & 8078 & 40.39 & IX \\
\hline 7. & ENT & 9014 & 45.07 & VII \\
\hline 8. & Physiotherapist & 8552 & 42.76 & VIII \\
\hline 9. & Pediatrics & 12520 & 56.08 & I \\
\hline
\end{tabular}


handling and service recovery systems patients, but also helps employees such as should be strengthened to enhance doctors and nurses, and managers in order to effectiveness of services.

\title{
16. CONCLUSION
}

In the health care business, technology is really important in managing the customer and employee relationship to guarantee the best service, and most important of all prevent errors. That is because in the area of healthcare, a small mistake might lead to a permanent error or even death. This is made possible by using special application healthcare software. Nowadays, many healthcare centers use special application software in order to run their services. Many companies develop software compete to provide the market with the best software, which guarantees high performance, and thus more benefits for employees, and of course for the patients.

Technology is healthcare not only support take the right decisions. Healthcare software helps in managing the duties of each employee, and givens the bottom line for important decisions on how to deal with different situations. In an industry such as medical health care, the main keys are speed and accuracy. That is because, as we mentioned earlier, the industry affects patients' lives directly. So technology is a major element in this industry in order to guarantee the best treatment for the patients, and the best coordination of employees. For example, a CRM system can transform a patient's medical record into an analytical tool for optimizing the care of each patient individually. Not only do organizations use CRM systems or detecting, reporting, and correcting the sources of fraudulent activities, but also helps them to proactively evaluate the quality of patient care and how the workers are performing their daily tasks.

\section{УПРАВЉАЊЕ ОДНОСОМ СА КУПЦИМА У ПРИВАТНИМ КЛИНИКАМА - СТУДИЈА ГРАДА НОИДА У ПОКРАИНИ УТАР ПРАДЕШ}

\author{
Saroj Kumar Dash ${ }^{a^{*}}$ and Arun Kumar Panda ${ }^{b}$

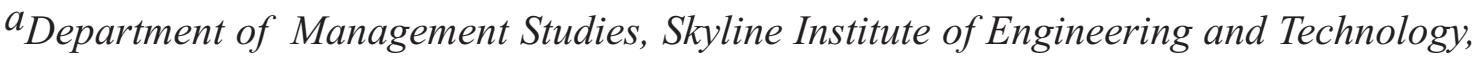 \\ Greater Noida, Uttar Pradesh, India-201308

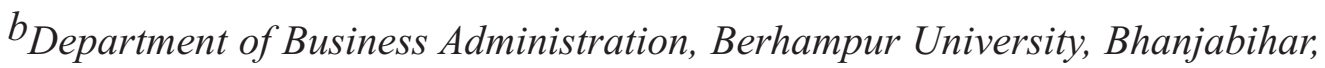 \\ Orissa, India
}

\section{Извод}

Менаџмент односа са купцима који има суштински значај у било ком пословању није ништа мање важан за управљање болницама. Болнице су најважнији елемент било којег здравственог система. Болнице играју главну улогу у одржавању и обнављању здравља људи. Један од најважнијих ресулрса у болницама је људски ресурс. Ово не треба заборавити из разлога што однос према медицинском особљу игра важну улогу према њиховом односу са пацијентима. 
Овај рад чини покушај да се анализирају фактори који утичу на пацијенте при избору болнице и да се предложе бољи начини задобијања поверења пацијената. У овој студији, истраживач је сакупио податке од 200 испитаника из 10 приватних болница смештених у граду Ноида. У циљу селекције узорка коришћен је метод засићеног случајног узорка. Представљена студија истиче ниво примене услуге болница од стране испитаника. Главни показатељ услужног сектора, посебно што се тиче показатеља болница, је пројектовање ових служби према очекивањима пацијената (купаца). Сакипљени подаци су анализирани преко дескриптивне статистике. Такође, примењен je Chi-square тест како би се направила процена укупног задовољства у односу на различите демографске показатеље. Оцена у упитнику је квантификована Ликерт-овом петостепеном скалом, како би се идентификовале преференце купаца и њихово задовољство услугом у болници. За оцену услуге, коришћен je Henry Garretов метод рангирања.

Кључне речи: Менаџмент односа са купцима, Задовољство купаца, Garret-ов метод рангирања

\section{References}

Basu, D.F. (2003) Healthcare: India's nest tourism booster, United Press International.

Berman, P. \& Dave, P.(1994). Experiences in paying for health care in India's voluntary sector. In: Pachauri S(ed).Reaching India's poor: Nongovernmental approaches to community health, New Delhi: Sage Publication.

Government of India (2004). Health Sector Reforms in India: Initiatives from States-II, Ministry of Health and Family Welfare in Collaboration with WHO Country Office for India, New Delhi.

Gupta, S. P. (2000). Statistical Methods. Sultan Chand \& Sons Publications, New Delhi.

James, F. E., Blackwell, R.D., \& Kollat, D.T., (2003). "Consumer Behaviour" The Dryden Press, New Delhi.

Kothari, C. R. (1990). Research Methodology Methods \& Techniques. Wishwa Prakashan, New Delhi.

Kotler, P. (2000). Marketing Management. The Millennium Edition, Prentice - Hall of India Private Limited, New Delhi.
Pillai, R. S. N., \& Bagavathi, (2009). Modern Marketing Principles and Practices. Second Revised and Enlarged Editions. S. Chand and Company Limited, New Delhi.

Rajan, N. N, (2009). Marketing management. Seventh Edition, Sultan Chand and Sons Publications, New Delhi.

Revathy, L. N., (2003). Health Care Spending May Cross Rs.2,00,000 Crore Mark. The Hindu Business Line.

Rohit, S, (2004) Too Many Crooks. India Today.

Shela R. H., (2003) India bids for Healthcare Tourism. Asia Times Online.

Stanton, W. J. (2009). Fundamentals of Marketing. International Edition, McGraw Hill Publishing Company, New Delhi.

Umukoro, F.G., Kuye, O.L., \& Sulaimon A.H. A. (2009) Matching strategies to situations: Progremmed and adaptive implementation approach, Serbian Journal of Management 4 (2): 259 - 272.

Živković, D., Živković, Ž., Manasijević, D., \& Kostadinović, M. (2010) Investigation of the knowledge combination interrelations between SMEs and consumer/supplier network, Serbian Journal of Management 5 (2): $261-269$. 